\title{
Energy Expenditure, Inflammation, and Oxidative Stress in Steady-State Adolescents With Sickle Cell Anemia
}

\author{
SYLVIE A. AKOHOUE, SADHNA SHANKAR, GINGER L. MILNE, JASON MORROW, KONG Y. CHEN, \\ WILFRED U. AJAYI, AND MACIEJ S. BUCHOWSKI
}

\begin{abstract}
Center for Nutrition and Department of Family and Community Medicine, Meharry Medical College [S.A.A., M.S.B.], Nashville, Tennessee 37208; Departments of Pediatrics [S.S.], Medicine [S.A.A., G.L.M., J.M., K.Y.C., M.S.B.], and Pediatrics Infectious Diseases [W.U.A.], Vanderbilt University Medical Center, Nashville, Tennessee 37232
\end{abstract}

\begin{abstract}
Sickle cell anemia (HbSS) is characterized by hypermetabolism, chronic inflammation, and increased oxidative stress, but the relationship between these factors is undefined. In this study, we examined indicators of inflammatory process and markers of oxidative damage and their impact on resting energy expenditure (REE) in stable HbSS adolescents $(n=35)$ and healthy controls carrying normal hemoglobin genotype (HbAA) $(n=39)$. C-reactive protein (CRP), white blood cell (WBC) count, and proinflammatory cytokines were measured as markers of inflammation and 2,3-dinor5,6-dihydro-15- $\mathrm{F}_{2 \mathrm{t}}$-isoprostane (F2-IsoPM) as a marker of oxidative stress. REE was measured by indirect calorimetry. WBC counts $\left(11.90 \pm 5.3 \times 10^{3} / \mu \mathrm{L}\right.$ versus $\left.5.6 \pm 1.9 \times 10^{3} / \mu \mathrm{L} ; p<0.001\right)$, serum CRP $(9.1 \pm 11.0 \mu \mathrm{g} / \mathrm{mL}$ versus $0.4 \pm 0.7 \mu \mathrm{g} / \mathrm{mL} ; p<0.001)$ and serum IL-8 (7.5 $\pm 4.4 \mathrm{pg} / \mathrm{mL}$ versus $5.5 \pm 4.8 \mathrm{pg} / \mathrm{mL} ; p=0.011)$ were higher in HbSS than HbAA, suggesting an anti-inflammatory response in HbSS. Higher urinary F2-IsoPM in HbSS $(1.2 \pm 0.4$ versus $0.7 \pm 0.3 \mathrm{ng} / \mathrm{mg}$ creatinine; $p<0.001)$ indicates increased oxidative stress. Fat free mass (FFM), hemoglobin ( $\mathrm{Hgb})$, interleukin (IL)-8, and F2-IsoPM were independent predictors of REE in HbSS (overall $r^{2}=0.778 ; p<0.001$ ). Low-grade inflammation and increased oxidative stress are present in adolescents with $\mathrm{HbSS}$ in the absence of acute crisis, and their markers are correlated with elevated REE. (Pediatr Res 61: 233-238, 2007)
\end{abstract}

$\mathrm{P}^{\mathrm{s}}$ atients with sickle cell anemia (HbSS) suffer from acute, painful vaso-occlusion crises, infections, and lifethreatening acute chest syndrome $(1,2)$. The period between the painful crises, during which the patient is symptom free, is considered the steady state (3). When compared with healthy controls (HbAA), patients with HbSS are hypermetabolic and show several abnormalities of the immune system, including high WBC counts, elevated serum levels of acute phase proteins such as CRP and of proinflammatory cytokines (4-6).

Sickled red blood cells from Hgb deoxygenation are a significant source of reactive oxygen species (free radicals) (7-9), which may be involved in the pathogenesis of vaso-

Received March 9, 2006; accepted September 29, 2006.

Correspondence: Maciej Buchowski, Ph.D., Center for Nutrition, Meharry Medical College, 1005 DB Todd Boulevard, Nashville, TN 37208; e-mail: maciej.buchowski@ vanderbilt.edu

Study supported in part by National Institutes of Health grants M01 RR00095 and by funds from GM008037, GM15431, CA77839, DK48831, and ES13125. M.S.B. was supported by HL677715.

Presented in part at the 27th and 28th annual Meetings of the Comprehensive Sickle Cell Disease Centers program.

DOI: $10.1203 / p d r .0 b 013 e 31802 d 7754$ occlusion and acute chest syndrome in sickle cell disease and promote the formation of a series of prostaglandin-like compounds such as $F_{2}$ isoprotanes $(10,11)$. These compounds are produced in vivo in human tissues from free radical-catalyzed peroxidation of membrane-bound arachidonic acid, a reaction that occurs independently of the cyclooxygenase enzyme (12).

$\mathrm{F}_{2}$ isoprotanes have been used as clinical markers of oxidative stress in various chronic diseases (13-15). In the present study, oxidative status was assessed by urinary levels of F2-IsoPM, an abundant $\beta$-oxidation metabolite of 8-isoprostaglandin- $F_{2}$, which is most frequently used in human studies as an index of oxidative status (16).

Increased REE is a major metabolic change associated with HbSS. We and others have shown that in symptom-free children and adolescents with HbSS, REE is approximately 15\%-20\% higher than in HbAA (17-19). This alteration in REE has been attributed to higher cardiac output and increased protein turnover (20) and was also shown to be associated with inflammation (5). However, a potential role of oxidative stress in aberrations of energy metabolism in $\mathrm{HbSS}$ is unknown. We hypothesized that increased inflammatory and oxidative processes could contribute to the increased REE observed in steady-state HbSS. To test this hypothesis, we measured REE, markers of inflammation (CRP, proinflammatory cytokines), circulating WBCs, reticulocyte proportion (RetCt\%), and marker of oxidative stress (F2-IsoPM) and assessed their effect on REE in a group of steady-state HbSS adolescents and matched HbAA.

\section{MATERIALS AND METHODS}

Study population. Thirty-five African-American 9- to 15-y-old adolescents with HbSS and 39 Tanner stage matched adolescent HbAA were studied at the Vanderbilt University General Clinical Research Center (GCRC). They were participants of a 3-y prospective study designed to assess metabolic consequences of HbSS in adolescence. The age range was chosen because the growth spur in adolescence could affect energy metabolism. HbSS adolescents were identified and screened for participation in the study at the Pediatric Sickle Cell Clinic at Vanderbilt in Nashville and at the MidSouth Sickle Cell

Abbreviations: CRP, C-reactive protein; F2-IsoPM, 2,3-dinor-5,6-dihydro15- $\mathrm{F}_{2 \mathrm{t}}$-isoprostane; FFM, fat free mass; FM, fat mass; GCRC, General Clinical Research Center; HbAA, healthy controls carrying normal hemoglobin genotype; HbSS, sickle cell anemia; Hgb, hemoglobin; REE, resting energy expenditure; RetCt\%, reticulocyte proportion; WBC, circulating white blood cell 
Clinic in Memphis, TN. HbSS participants included 22 boys and 13 girls. The control group consisted of 19 boys and 20 girls and was also matched for weight and fat-free mass (FFM) with HbSS group. Standard electrophoresis methods were used to confirm the diagnosis of HbSS (21).

Patients with vaso-occlusive or pain crisis in the past $2 \mathrm{mo}$; receiving chronic transfusion; being on hydroxyurea therapy; having apparent metabolic, skeletal, hepatic, and renal dysfunction; or taking drugs known to affect energy metabolism as well as pregnant females were excluded from the study. To eliminate the influence of menstrual function on energy expenditure, females were tested for pregnancy, and, if menstruating, they were studied in a follicular phase of the menstrual cycle (22). At the beginning of the study, a medical history was obtained and participants underwent a complete physical examination. Adolescents and parents received written and verbal information about the nature and purpose of the study. Informed assent and consent was obtained from each study participant and parents at enrollment in accordance with the Declaration of Helsinki. The study protocol was approved by the Institutional Review Board at Meharry Medical College and Vanderbilt University School of Medicine.

Study protocol. Study participants were scheduled for a visit and admitted on the afternoon preceding the 3-d study to the GCRC at Vanderbilt University Medical Center. On that afternoon, weight, height, and body composition were measured. During the study, participant received a diet designed by a study dietitian and based on assessed requirements and individual preferences. The diet was prepared at the GCRC metabolic kitchen and contained $50 \pm 5 \%$ of the energy from carbohydrate, $30 \pm 3 \%$ from fat, and $15 \pm 3 \%$ from protein, and all required micronutrients. Participants spent the following day (0630 to 0630 the next day) in the whole-room indirect calorimeter, in a strictly controlled environment (temperature and humidity) and followed a standardized protocol. This approach eliminated possible influence of physical activity and, at least in part, other environmental factors on outcome variables. We have previously described the procedure in the room calorimeter (18).

Sample collection. Fasting blood samples were collected in evacuated blood collection tubes by venipuncture from an antecubital vein on the morning after the 24-h stay in the room calorimeter. Blood samples for cytokines analyses were allowed to clot at room temperature and centrifuged for $5 \mathrm{~min}$ in a refrigerated $\left(4^{\circ} \mathrm{C}\right)$ centrifuge at a speed of $3000 \mathrm{x} \mathrm{g}$. Urine was collected at specific times: on the day of admission (from arrival through the night), during (from 0600 to 2100 and throughout the night) and after the 24-h metabolic study (0600). Serum samples and urine specimens were immediately stored at $-80^{\circ} \mathrm{C}$ and $-70^{\circ} \mathrm{C}$, respectively, until analysis.

Analytical procedures. Hematological parameters (WBC count, RetCt \%, ferritin, albumin, platelet count, red blood cells, red blood cell folate, packed cell volume, and whole blood Hgb concentration), thyroid-stimulating hormone, growth hormone, and CRP were measured at Vanderbilt's hospital laboratory using standard methodology.

Cytokine measurement. A panel of human inflammation cytokines consisting of IL-1 $\beta$, IL-6, IL-8, IL-10, IL-12p70, and tumor necrosis factor $\alpha$ (TNF- $\alpha$ ) was measured using the Human Inflammation Cytokine Cytometric Bead array kit (BD Biosciences Pharmingen, San Diego, CA). The kit provides a mixture of six microbead populations precoated with captured antibodies specific for the inflammation cytokines and each with distinct fluorescent intensities. Amplified fluorescence detection was done by flow cytometry to quantify soluble protein in a bead-based immunoassay. FACs Scan Flow cytometry (BD Biosciences Pharmingen) was used for sample acquisition, and cytokine levels were quantified by their computed mean fluorescent intensity using the CBA software (BD Biosciences Pharmingen).

Isoprostane measurement. F2-IsoPM was purified from urine samples, derivatized, and quantified by gas chromatography/mass spectrometry with negative ion chemical ionization mass spectrometry (23). The assay has a very high accuracy $(97 \%)$ as determined by a standard curve and a precision of $\pm 4 \%$. The F2-IsoPM values were adjusted by urine creatinine.

Body composition. Body weight was measured to the nearest $0.05 \mathrm{~kg}$ with a digital scale with the participants wearing light clothing and no shoes. Fat mass (FM) and FFM were assessed by dual energy x-ray absorptiometry (DEXA, Lunar Prodigy, GE Medical Systems, Madison WI, children software, v. 9.15).

$\boldsymbol{R} \boldsymbol{E} \boldsymbol{E}$. REE ( $\mathrm{kcal} / \mathrm{min}$ ) was measured using a whole-room indirect calorimeter and was defined as the average energy expenditure during a 30-min period while the subject lay quietly in bed on the morning after an overnight sleep and $10 \mathrm{~h}$ of fasting. The amount of oxygen used $\left(\mathrm{VO}_{2}\right)$ and carbon dioxide expelled $\left(\mathrm{VCO}_{2}\right)$ was calculated by multiplying measured changes in $\mathrm{O}_{2}$ and $\mathrm{CO}_{2}$ concentration in the air sampled from inside the room calorimeter by the flow rate of the purged air on a minute-by-minute basis. The energy expenditure during periods when body motion was detected by a precision force platform was excluded from REE calculations (18). Regression models of REE based on predictors FFM and FM were used rather then division of REE by FFM, since division by FFM does not account for nonzero intercepts typically observed in these regressions (24).

Statistical analysis. Sample size was calculated using data from our preliminary study showing that there is a significant difference in 8-Iso-PGF $2 \alpha$ concentration, a major urinary metabolite, between $\operatorname{HbSS}(n=21)$ and $\mathrm{HbAA}$ $(n=25)(3.92 \pm 3.00 \mathrm{ng} / \mathrm{mg}$ creatinine versus $1.40 \pm 0.52 \mathrm{ng} / \mathrm{mg}$ creatinine; $p=0.001, t$ test). Using a two-sided $t$ test with a significance level of 0.05 , we calculated that 16 participants would provide $90 \%$ statistical power to detect difference between HbSS and HbAA. The Mann-Whitney $U$ test was used to compare variables between groups. Before analysis, cytokine and CRP values below the detection limit were set at $0.1 \mathrm{pg} / \mathrm{mL}$ and $0.001 \mathrm{ng} / \mathrm{mL}$, respectively. Multiple linear regression analysis was performed on REE by using a backward elimination approach. The covariates that were considered for inclusions in the modeling were FFM, sex (male versus female), Hgb, WBC, F2-IsoPM, IL-8, RetCt\%, and CRP. Association between variables was assessed by the Spearman's correlation test. Residual analysis was performed for evaluation of model adequacy and outliers. A $p$ value of $<0.05$ was considered statistically significant. Values in tables are reported as means \pm standard deviation (SD). Statistical analyses were performed using SPSS version 14.0 (SPSS Inc., Chicago, IL).

\section{RESULTS}

Subject characteristics and hematological parameters. Body weight, height, and FFM were not significantly different between HbSS and HbAA groups (Table 1). Percentage of body fat was not significantly different between HbSS and HbAA, but girls had a higher percentage of body fat than boys in either group (Table 1). In each group, FM was also significantly different between girls and boys $(13.9 \pm 9.6 \mathrm{~kg}$ versus

Table 1. Characteristics of study participants

\begin{tabular}{|c|c|c|c|c|}
\hline & \multicolumn{2}{|c|}{$\mathrm{HbSS}$} & \multicolumn{2}{|c|}{$\mathrm{HbAA}$} \\
\hline & Males $(n=22)$ & Females $(n=13)$ & Males $(n=19)$ & Females $(n=20)$ \\
\hline Age, y & $12.2 \pm 0.1^{*}$ & $12.4 \pm 1.8^{*}$ & $11.7 \pm 1.3$ & $11.1 \pm 1.2$ \\
\hline Weight, kg & $41.0 \pm 9.3$ & $49.4 \pm 16.3$ & $40.7 \pm 10.9$ & $47.0 \pm 13.0$ \\
\hline Height, $\mathrm{cm}$ & $147.3 \pm 14.0$ & $151.9 \pm 16.9$ & $147.7 \pm 10.9$ & $151.3 \pm 9.6$ \\
\hline Fat-free mass, $\mathrm{kg}$ & $31.3 \pm 5.3$ & $31.9 \pm 7.7$ & $33.9 \pm 9.3$ & $32.6 \pm 5.9$ \\
\hline Body fat, $\%$ & $18.9 \pm 8.3$ & $30.9 \pm 10.4 \dagger$ & $15.9 \pm 7.9$ & $26.4 \pm 12.2 \dagger$ \\
\hline REE, kcal/kg FFM/min & $0.036 \pm 0.004 *$ & $0.034 \pm 0.003^{*}$ & $0.033 \pm 0.005$ & $0.029 \pm 0.005$ \\
\hline TEE, kcal/day & $1899 \pm 307$ & $1951 \pm 382$ & $1921 \pm 418$ & $1973 \pm 344$ \\
\hline Thyroid hormone, $\mu \mathrm{U} / \mathrm{mL}$ & $2.98 \pm 1.50$ & $1.98 \pm 0.75$ & $2.53 \pm 1.25$ & $2.00 \pm 1.01$ \\
\hline Growth hormone, ng/mL & $0.51 \pm 0.43(0.1-1.5)$ & $3.12 \pm 2.86(0.1-6.9) \dagger$ & $0.50 \pm 1.11(0.1-4.7)$ & $1.00 \pm 2.00(0.1-8.3) \dagger$ \\
\hline
\end{tabular}

Values are expressed as means \pm SD (range).

* Significantly different from HbAA; $p<0.001$ for age and $p<0.0001$ for REE.

$\dagger$ Significantly different between genders within group; $p=0.006$ for body fat and $p=0.048$ for growth hormone. 
Table 2. Laboratory data from HbSS patients and adolescent $H b A A$

\begin{tabular}{|c|c|c|c|c|}
\hline & \multicolumn{4}{|c|}{ HbSS HbAA } \\
\hline & Males $(n=22)$ & Females $(n=13)$ & Males $(n=19)$ & Females $(n=20)$ \\
\hline $\mathrm{Hbg}, \mathrm{g} / \mathrm{dL}$ & $9.72 \pm 2.43 *(6.4-14.0)$ & $9.95 \pm 1.20 *(8.5-12.9)$ & $13.73 \pm 1.00(11.3-15.5)$ & $13.82 \pm 1.30(11.6-16.5)$ \\
\hline WBCs, $10^{3} / \mathrm{L}$ & $11.27 \pm 5.72 *(4.3-22.2)$ & $12.85 \pm 4.60 *(4.5-21)$ & $5.60 \pm 2.16(2.7-10.9)$ & $5.54 \pm 1.69(3.5-8.3)$ \\
\hline $\mathrm{RetCt} \%$ & $9.75 \pm 6.32 *(2.1-21.4)$ & $9.71 \pm 4.51 *(1.9-17.4)$ & $1.01 \pm 0.35(0.4-1.9)$ & $1.20 \pm 0.34(0.6-1.8)$ \\
\hline Packed cell volume, \% & $27.75 \pm 6.54 *(19-40)$ & $29.15 \pm 3.87 *(24-39)$ & $40.63 \pm 2.36(36-44)$ & $40.90 \pm 2.55(36-45)$ \\
\hline Platelet count, $10^{3} / \mathrm{L}$ & $368 \pm 173 *(81-636)$ & $458 \pm 204 *(232-927)$ & $280 \pm 44(212-367)$ & $279 \pm 71(185-458)$ \\
\hline RBCs, million/L RBCs & $3.50 \pm 1.13 *(2.1-5.4)$ & $3.58 \pm 0.84 *(2.7-5.8)$ & $5.07 \pm 0.28(4.3-5.4)$ & $5.11 \pm 0.49(4.4-5.9)$ \\
\hline $\mathrm{RBC}$ folate, $\mathrm{mg} / \mathrm{mL} \mathrm{RBCs}$ & $795 \pm 431 \dagger(179-1835)$ & $744 \pm 311 \dagger(308-1162)$ & $624 \pm 201(251-970)$ & $594 \pm 169(417-955)$ \\
\hline Ferritin, mg/mL & $359 \pm 326^{*}(18-1055)$ & $631 \pm 1212 *(34-4426)$ & $41.05 \pm 6.83(16-86)$ & $45.24 \pm 26.04(6-112)$ \\
\hline Albumin, g/dL & $4.54 \pm 0.37(3.9-5.4)$ & $4.24 \pm 0.33(3.6-4.6)$ & $4.43 \pm 0.30(4-5)$ & $4.36 \pm 0.40(3.7-5.3)$ \\
\hline
\end{tabular}

RBCs, red blood cells. Values are expressed as means \pm SD (range). All $p$ values $<0.001$.

${ }^{*}$ Significantly different from HbAA.

$\dagger$ Significantly higher than HbAA when corrected for RBC count.
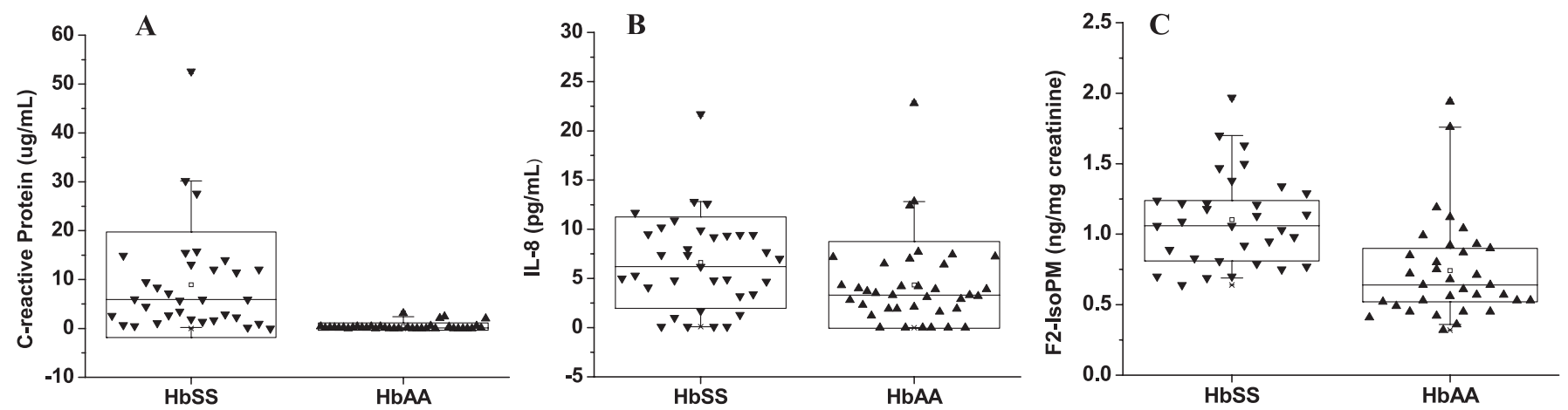

Figure 1. Comparison of CRP, IL-8, and urinary isoprostane (F2-IsoPM) levels in HbSS patients and HbAA. Each triangle represents individual observation. CRP $(p<0.001)(A)$, IL-8 $(p=0.011)(B)$, and F2-IsoPM $(p<0.001)(C)$ were significantly higher in HbSS patients $(n=35)$ than in adolescent $\operatorname{HbAA}(n=39)$.

$6.49 \pm 4.2 \mathrm{~kg}$ in $\mathrm{HbAA} ; p=0.001$ and $16.2 \pm 10.6 \mathrm{~kg}$ versus $8.3 \pm 5.0 \mathrm{~kg}$ in HbSS; $p=0.006$ ). Levels of thyroidstimulating hormone and growth hormone were in the normal range and did not differ between HbSS and HbAA (Table 1). $\mathrm{HbSS}$ girls had slightly higher plasma concentration of growth hormone than HbSS boys ( $p=0.048$ ) (Table 1$)$. As expected, most of hematological parameters were significantly different between HbSS and HbAA (Table 2).

C-reactive protein. CRP concentration was significantly higher in HbSS patients than HbAA. Mean values were 9.12 (range, 0.2-52.6) $\mu \mathrm{g} / \mathrm{mL}$ versus 0.39 (range, 0.001-3.1) $\mu \mathrm{g} / \mathrm{mL}(p<0.001)$; (Fig. $1 A)$. Of the 35 steady-state HbSS patients, only four (11\%) had a serum CRP concentration $<0.50 \mu \mathrm{g} / \mathrm{mL}$ or not detectable. Twelve $(34 \%)$ of the HbSS patients had CRP levels ranged between 1 and $5 \mu \mathrm{g} / \mathrm{mL}$ and $>50 \%$ had a CRP concentration ranging between 5.7 and 52.6 $\mu \mathrm{g} / \mathrm{mL}$ and averaging $15.6 \mu \mathrm{g} / \mathrm{mL}$. Serum CRP of the majority $(89 \%)$ of HbAA was either $<0.5 \mu \mathrm{g} / \mathrm{mL}$ or not detectable. In the $\mathrm{HbSS}$ group, CRP concentration was significantly correlated with IL-8 (Spearman rho $=0.410 ; p=0.022$ ) (Fig. $2 A)$.

Serum cytokines. IL- 8 was significantly higher in the HbSS patients when compared with HbAA $(7.5 \pm 4.4$ versus $5.5 \pm$ $4.8 \mathrm{pg} / \mathrm{mL} ; p=0.011$ ) (Fig. $1 B$ ). Differences between HbSS and HbAA in IL-1 $\beta$, IL-6, IL-10, IL-12p70, and TNF- $\alpha$ serum concentration were not significant.

Isoprostanes and HBSS. Urinary F2-IsoPM was significantly higher in $\mathrm{HbSS}$ patients than $\mathrm{HbAA}(1.15 \pm 0.37$ $\mathrm{ng} / \mathrm{mg}$ creatinine versus $0.74 \pm 0.35 \mathrm{ng} / \mathrm{mg}$ creatinine; $p<$ 0.001) (Fig. 1C). F2-IsoPM was correlated with IL-8 (Spearman rho $=0.350 ; p=0.05)$ (Fig. $2 B)$ and RetCt\% $(r=0.447$; $p<0.001)$. There was also a significant correlation between F2-IsoPM and REE adjusted for FFM (Spearman rho = 0.343; $p=0.006)$.

Energy expenditure, oxidative stress, and inflammation. As expected, REE was higher in $\operatorname{HbSS}$ than $\operatorname{HbAA}(p<$ 0.001 ) (Table 1). FFM ( $p<0.001)$, sex (male versus female; $p=0.06)$, and disease status (HbSS versus $\mathrm{HbAA} ; p=0.008)$ were significant predictors of REE (overall adjusted $r^{2}=$ $0.658 ; p<0.001)$. Multiple regression analysis in $\mathrm{HbSS}$ adolescents showed that also $\mathrm{Hgb}(p=0.010)$, F2-IsoPM $(p=0.058)$, and IL-8 $(p=0.001)$ were significant predictors
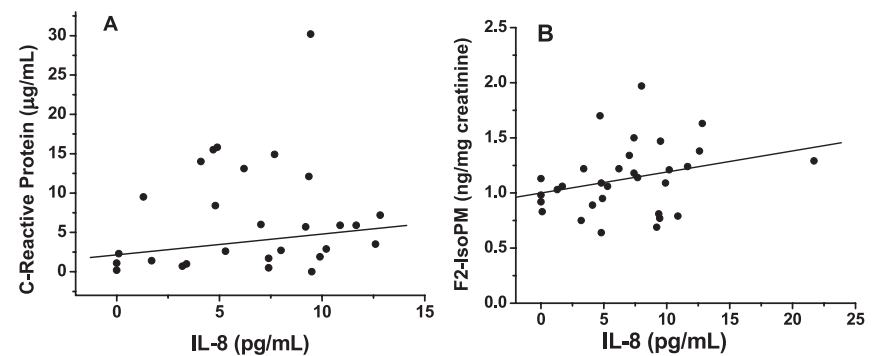

Figure 2. Correlation between IL-8 and CRP (Spearman rho $=0.410 ; p=$ $0.022)(A)$ and IL-8 and urinary F2-IsoPM (Spearman rho $=0.350 ; p=0.05$ ) $(B)$ in adolescent $\mathrm{HbSS}(n=35)$. 
Table 3. Multiple regression model results for REE ( $\mathrm{kcal} / \mathrm{min})$ in HbSS adolescents $(n=35)$

\begin{tabular}{|c|c|c|c|c|}
\hline & \multicolumn{4}{|c|}{$\mathrm{REE}(\mathrm{kcal} / \mathrm{min})$} \\
\hline & Coefficient & $\begin{array}{c}\text { Standard } \\
\text { error }\end{array}$ & $p$ & $\begin{array}{c}\text { Overall } \\
\text { adjusted } R^{2}\end{array}$ \\
\hline Intercept & 0.651 & 0.115 & & 0.788 \\
\hline FFM, kg & 0.025 & 0.003 & $<0.0001$ & \\
\hline Sex & 0.035 & 0.032 & 0.285 & \\
\hline $\mathrm{Hgb}, \mathrm{g} / \mathrm{dL}$ & -0.034 & 0.012 & 0.01 & \\
\hline $\mathrm{IL}-8, \mathrm{pg} / \mathrm{mL}$ & -0.013 & 0.003 & 0.001 & \\
\hline $\mathrm{F}_{2}$-IsoPM, ng/mg creatinine & 0.086 & 0.043 & 0.058 & \\
\hline
\end{tabular}

Sex codes: 0 , males; 1 , females.
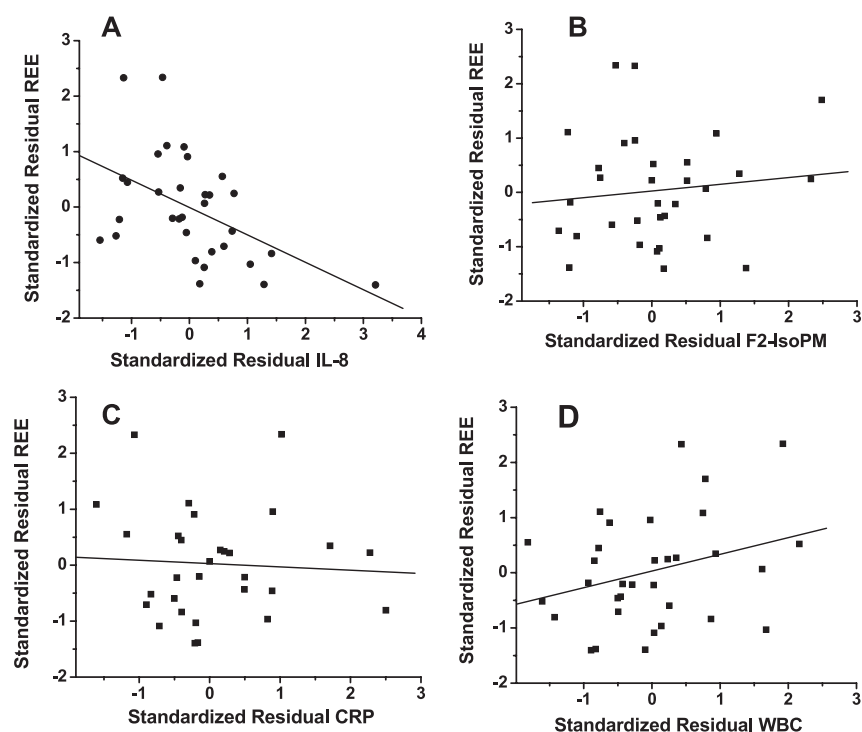

Figure 3. Standard residual plots of resting energy expenditure (REE) against IL-8 $(A ; r=-0.499, p=0.005)]$, urinary F2-IsoPM $(B ; r=0.117, p>0.05)$, $\mathrm{CRP}(C ; r=-0.60 ; p>0.05)$, and WBCs $(D ; r=0.300, p>0.05)$ after all have been adjusted for the effect of FFM and Hgb in adolescent HbSS $(n=35)$.

of REE (overall adjusted $r^{2}=0.788$ ) (Table 3). Standardized residuals of IL-8 and F2-IsoPM, CRP, and WBCs were plotted against standardized residuals of REE when all were adjusted for the effect of FFM and Hgb (Fig. 3A-D).

\section{DISCUSSION}

This study shows that both low-grade inflammation and elevated oxidative stress were present in absence of clinical acute crises in adolescents with HbSS. Furthermore, elevated level of inflammation and oxidative stress markers were associated with higher rates of REE.

Sickle cell disease has been characterized as an inflammatory condition due to abnormally high leukocyte counts (25) and increased levels of WBCs during and after vaso-occlusive crises or acute chest syndrome (26). In a recent study, an association of inflammation with hypermetabolism has been documented in HbSS children (5). Our study extends these findings by showing that steady-state HbSS adolescents, in addition to a low-grade inflammation, have elevated level of F2-IsoPM, suggesting increased oxidative stress. The results also support our hypothesis that increased inflammatory and oxidative processes are correlated with elevated REE observed in HbSS.

CRP is an acute-phase protein that is produced by hepatocytes upon stimulation by the cytokines IL- 6 , IL- 8 , IL- $1 \beta$, and $\mathrm{TNF}-\alpha$. Its primary role is to both enhance the immune system and protect against tissue damage. As a marker of inflammation, CRP has been used to predict prognosis and relapse in patients with some chronic diseases as well as morbidity in others (27). In this study, we found that CRP concentration was higher in HbSS than in HbAA, suggesting a covert inflammatory response despite the absence of crisis. Intracellular sickle $\mathrm{Hgb}$ polymerization is a major factor in the abnormality of sickle erythrocytes. It was proposed that this abnormality may contribute to oxidative damage of the lipid bilayer and membrane integrity in sickle cell disease (10). Thus, the elevated CRP in HbSS may be in response to endothelium damage due to the blockage of the vascular endothelium by sickled erythrocytes.

In comparing the cytokine pattern, we found that IL-8 was significantly higher in HbSS than in HbAA. IL-8 is a proinflammatory cytokine whose primary function during infection and inflammation may involve the recruitment and activation of neutrophils and lymphocytes to the site of tissue damage. Earlier investigations revealed that expression of IL-8 is associated with inflammation (28). Because of a high interindividual variations in IL-8 level in both groups (Fig. 1B), a clinical importance of this difference is unclear and requires further investigation.

We did not observe any significant increase in the level of other inflammatory cytokines such as IL-6. This and the lack of a significant correlation between REE and the cytokines suggest that observed increased REE was not a result of metabolic aberrations characteristic to the acute stress. Higher RetCt\%, CRP, and WBCs count may rather confirm a notion that HbSS is a form of chronic inflammatory condition (29). These results are similar to a recent study by Hibbert and colleagues (5), indicating an unusual inflammatory profile in children with HbSS. The authors postulated that significantly reduced monocyte chemoattractant protein-1, leptin, and IL-10 and increased CRP and IL-6 observed in their study may represent a sum of compensatory mechanism to control possible harmful effects of chronic hyperinflammation in HbSS.

In our assessment of oxidative stress using components of the $\mathrm{F}_{2}$ isoprotane family as markers, we found that urinary excretion of F2-IsoPM was significantly higher in the HbSS patients than in $\mathrm{HbAA}$. It has been reported that acute chest syndrome in HbSS causes a ninefold increase in plasma $\mathrm{F}_{2}$ isoprostanes when compared with normal volunteers (14). The authors concluded that although the sources of free-radical generation were likely to be multiple, the reduction of oxygen delivery to tissues in the acute chest syndrome favors the formation of oxygen-related radicals, which can react with nitric oxide to form other oxygen-nitrogen reactive compounds. It is worth noting that in that study, there was 10 -fold interindividual variability. These results, however, were not discussed by the authors, probably because of a small sample number $(n=5)$. In our present study, we also found a 
substantial interindividual variability in the F2-IsoPM level (Fig. 1C), which can be attributed to a variability in the oxidative stress alterations in our clinically asymptomatic $\mathrm{HbSS}$ patients. Proposed mechanisms for the increase of $F_{2}$ isoprostanes in $\mathrm{HbSS}$ include alterations in antioxidant defense systems and elevated levels of $\mathrm{O}_{2}$ and hydrogen peroxide $\left(\mathrm{H}_{2} \mathrm{O}_{2}\right)(30,31)$.

Elevated REE is another key component of diseases associated with inflammatory conditions $(5,32)$. It is well documented that REE is $15 \%-20 \%$ higher in HbSS children and adolescents than in HbAA (17-19). Postulated mechanisms of this increase include elevated cardiac output, necessitated by the low oxygen-carrying capacity of the blood and increased protein turnover in $\mathrm{HbSS}(20,33)$. We have estimated that approximately $50 \%$ of the increase in REE is due to increased protein synthesis requirements (34). This study shows that REE is correlated with biomarkers of both chronic inflammation (IL-8) and oxidation (F2-IsoPM), and thus these factors may contribute to the increased REE in steady-state adolescents with HbSS. Whether increased WBC count and subsequent production of proinflammatory cytokines in HbSS is due to oxidative damage or caused by inflammation warrants further investigations.

Our study must be interpreted within the context of our experimental design. We have assumed that measured biomarker levels were directly linked to oxidation and inflammation. These markers, however, are indirect measurements of oxidation and inflammation. There is also a possibility that the isoprostanes formed are not a result of lipid peroxidation, but are a marker of increased cyclooxygenase turnover, which has been demonstrated in patients with sickle cell disease (35). Although formation of isoprostanes via a cyclooxygenasemediated mechanism could occur, it usually produces a trivial amount of these compounds (12). Thus, cyclooxygenase turnover was not likely to have produced the increases in isoprostane levels we observed. Another limitation is that we could not determine whether the increased level of F2-IsoPM observed in HbSS was caused by the increased production of reactive oxygen species or by the decreased antioxidant defense mechanism. Choosing to study only patients with no vaso-occlusive crisis within 2 mo may also have biased the study toward a subgroup of sickle cell anemia with less frequent pain and perhaps more hemolysis and endothelial dysfunction $(36,37)$. In our analyses, we did not take under consideration elevated plasma ferritin levels in HbSS adolescents. Ferritin is an acute phase reactant and its elevation in HbSS might be a sign of chronic inflammation (38). However, the relationship between plasma ferritin and inflammation might be distorted by previous transfusions, ascorbate deficiency, fever, infection, and hepatic dysfunction, all of which could occur in patients with sickle cell disease (39). Finally, the study cannot answer the question of how much inflammation contributed to the observed higher REE in HbSS adolescents.

In summary, our findings suggest that low-grade inflammation and increased oxidative stress present in steady-state HbSS adolescents are correlated with elevated REE.
Acknowledgments. The authors thank the staff of the General Clinical Research Center at Vanderbilt University for help with this project. They also thank Kay Hongu, Ph.D., and Cindy Dorminy, M.Ed., for their technical assistance; Dan Byrne, M.S., for statistical expertise in analyzing the data; and Leena Choi, Ph.D., for helping with graphic data presentation. Finally, they acknowledge our participants and their parents for their enthusiasm and commitment to this study.

\section{REFERENCES}

1. Bunn HF 1997 Pathogenesis and treatment of sickle cell disease. N Engl J Med 337:762-769

2. Embury SH, Hebbel RP, Steinberg MH, Mohandas N 1994 Pathogenesis of vasoocclusion. In: Embury SH, Hebbel RP, Mohandas N, Steinberg MH (eds) Sickle Cell Disease: Basic Principles and Clinical Practice. Lippincott-Raven, Philadelphia, pp 311-326

3. Akinola NO, Stevens SM, Franklin IM, Nash GB, Stuart J 1992 Subclinical ischaemic episodes during the steady state of sickle cell anaemia. J Clin Pathol 45:902-906

4. Duits AJ, Schnog JB, Lard LR, Saleh AW, Rojer RA 1998 Elevated IL-8 levels during sickle cell crisis. Eur J Haematol 61:302-305

5. Hibbert JM, Hsu LL, Bhathena SJ, Irune I, Sarfo B, Creary MS, Gee BE, Mohamed AI, Buchanan ID, Al-Mahmoud A, Stiles JK 2005 Proinflammatory cytokines and the hypermetabolism of children with sickle cell disease. Exp Biol Med (Maywood) 230:68-74

6. Makis AC, Hatzimichael EC, Stebbing J, Bourantas KL 2006 C-reactive protein and vascular cell adhesion molecule-1 as markers of severity in sickle cell disease. Arch Intern Med 166:366-368

7. Hebbel RP, Eaton JW, Balasingam M, Steinberg MH 1982 Spontaneous oxygen radical generation by sickle erythrocytes. J Clin Invest 70:1253-1259

8. Hebbel RP 1991 Beyond hemoglobin polymerization: the red blood cell membrane and sickle disease pathophysiology. Blood 77:214-237

9. Klings ES, Farber HW 2001 Role of free radicals in the pathogenesis of acute chest syndrome in sickle cell disease. Respir Res 2:280-285

10. Aslan M, Thornley-Brown D, Freeman BA 2000 Reactive species in sickle cell disease. Ann N Y Acad Sci 899:375-391

11. Jain SK, Shohet SB 1984 A novel phospholipid in irreversibly sickled cells: evidence for in vivo peroxidative membrane damage in sickle cell disease. Blood 63:362-367

12. Morrow JD, Hill KE, Burk RF, Nammour TM, Badr KF, Roberts LJ 2nd 1990 A series of prostaglandin F2-like compounds are produced in vivo in humans by a non-cyclooxygenase, free radical-catalyzed mechanism. Proc Natl Acad Sci U S A 87:9383-9387

13. Davi G, Ciabattoni G, Consoli A, Mezzetti A, Falco A, Santarone S, Pennese E, Vitacolonna E, Bucciarelli T, Costantini F, Capani F, Patrono C 1999 In vivo formation of 8-iso-prostaglandin F2\{alpha $\}$ and platelet activation in diabetes mellitus :effects of improved metabolic control and vitamin E supplementation. Circulation 99:224-229

14. Klings ES, Christman BW, McClung J, Stucchi AF, McMahon L, Brauer M, Farber HW 2001 Increased F2 isoprostanes in the acute chest syndrome of sickle cell disease as a marker of oxidative stress. Am J Respir Crit Care Med $164: 1248-1252$

15. Psathakis K, Papatheodorou G, Plataki M, Panagou P, Loukides S, Siafakas NM, Bouros D 2004 8-Isoprostane, a marker of oxidative stress, is increased in the expired breath condensate of patients with pulmonary sarcoidosis. Chest 125:1005-1011

16. Roberts LJ, Morrow JD 2000 Measurement of $\mathrm{F}(2)$-isoprostanes as an index of oxidative stress in vivo. Free Radic Biol Med 28:505-513

17. Barden EM, Zemel BS, Kawchak DA, Goran MI, Ohene-Frempong K, Stallings VA 2000 Total and resting energy expenditure in children with sickle cell disease. J Pediatr 136:73-79

18. Buchowski MS, Chen KY, Byrne D, Wang WC 2002 Equation to estimate resting energy expenditure in adolescents with sickle cell anemia. Am J Clin Nutr 76:13351344

19. Salman EK, Haymond MW, Bayne E, Sager BK, Wiisanen A, Pitel P, Darmaun D 1996 Protein and energy metabolism in prepubertal children with sickle cell anemia. Pediatr Res 40:34-40

20. Buchholz AC, Buchowski MS 2004 Energy and protein metabolism in sickle cell disease: Evidence of aberrations. In: Focus on Sickle Cell Research. Plasmar RL (ed). Nova Science Publishers, Hauppauge, NY, pp 1-17

21. Adams JG 3rd 1994 Clinical laboratory diagnosis. In: Embury SH, Hebbel RP, Mohandas N, Steinberg MH (eds) Sickle Cell Disease: Basic Principles and Clinical Practice. Lippincott-Raven, Philadelphia, pp 457-468

22. Henry CJ, Lightowler HJ, Marchini J 2003 Intra-individual variation in resting metabolic rate during the menstrual cycle. Br J Nutr 89:811-817

23. Morrow JD, Zackert WE, Yang JP, Kurhts EH, Callewaert D, Dworski R, Kanai K, Taber D, Moore K, Oates JA, Roberts LJ 1999 Quantification of the major urinary metabolite of 15-F2t-isoprostane (8-iso-PGF2[alpha]) by a stable isotope dilution mass spectrometric assay. Anal Biochem 269:326-331

24. Poehlman ET, Toth MJ 1995 Mathematical ratios lead to spurious conclusions regarding age- and sex- related differences in resting metabolic rate. Am J Clin Nutr $61: 482-485$ 
25. Chies JA, Nardi NB 2001 Sickle cell disease: a chronic inflammatory condition. Med Hypotheses 57:46-50

26. Goncalves MS, Queiroz IL, Cardoso SA, Zanetti A, Strapazoni AC, Adorno E, Albuquerque A, Sant'Ana A, dos Reis MG Barral A, Barral Netto, M 2001 Interleukin 8 as a vaso-occlusive marker in Brazilian patients with sickle cell disease. Braz J Med Biol Res 34:1309-1313

27. Ridker PM, Hennekens CH, Buring JE, Rifai N 2000 C-reactive protein and other markers of inflammation in the prediction of cardiovascular disease in women. N Engl J Med 342:836-843

28. Harada A, Mukaida N, Matsushima K 1996 Interleukin 8 as a novel target for intervention therapy in acute inflammatory diseases. Mol Med Today 2:482-489

29. Okpala I 2006 Leukocyte adhesion and the pathophysiology of sickle cell disease. Curr Opin Hematol 13:40-44

30. Hammerman SI, Klings ES, Hendra KP, Upchurch JrGR Rishikof DC, Loscalzo J, Farber HW 1999 Endothelial cell nitric oxide production in acute chest syndrome. Am J Physiol 277:H1579-H1592

31. Kaul DK, Hebbel RP 2000 Hypoxia/reoxygenation causes inflammatory response in transgenic sickle mice but not in normal mice. J Clin Invest 106:411-420

32. Utaka S, Avesani CM, Draibe SA, Kamimura MA, Andreoni S, Cuppari L 2005 Inflammation is associated with increased energy expenditure in patients with chronic kidney disease. Am J Clin Nutr 82:801-805
33. Badaloo A, Jackson AA, Jahoor F 1989 Whole body protein turnover and resting metabolic rate in homozygous sickle cell disease. Clin Sci (Lond) 77:93-97

34. Borel MJ, Buchowski MS, Turner EA, Goldstein RE, Flakoll PJ 1998 Protein turnover and energy expenditure increase during exogenous nutrient availability in sickle cell disease. Am J Clin Nutr 68:607-614

35. Wautier JL, Pintigny D, Maclouf J, Wautier MP, Corvazier E, Caen J 1986 Release of prostacyclin after erythrocyte adhesion to cultured vascular endothelium. J Lab Clin Med 107:210-215

36. Alexander N, Higgs D, Dover G, Serjeant GR 2004 Are there clinical phenotypes of homozygous sickle cell disease? Br J Haematol 126:606-611

37. Kato GJ, Martyr S, Blackwelder WC, Nichols JS, Coles WA, Hunter LA, Brennan ML, Hazen SL, Gladwin MT 2005 Levels of soluble endothelium-derived adhesion molecules in patients with sickle cell disease are associated with pulmonary hypertension, organ dysfunction, and mortality. Br J Haematol 130:943-953

38. Harmatz P, Butensky E, Quirolo K, Williams R, Ferrell L, Moyer T, Golden D, Neumayr L, Vichinsky E 2000 Severity of iron overload in patients with sickle cell disease receiving chronic red blood cell transfusion therapy. Blood 96:76-79

39. Brittenham GM, Cohen AR, McLaren CF, Martin MB, Griffith PM, Nienhuis AW, Young NS, Allen CJ, Farrell DE, Harris JW 1993 Hepatic iron stores and plasma ferritin concentration in patients with sickle cell anemia and thalassemia major. Am J Hematol 42:81-85 